\title{
The Influence of Corporate Governance on Intellectual Capital Disclosure: Evidence from Bank on Indonesian Stock
} Exchange 2015-2019

\section{Indrayati, ${ }^{1}$ Erlin Melani, ${ }^{2}$ Slamet ${ }^{3}$}

${ }^{1,2}$ Lecturer Accounting Department State Polytechnic of Malang, East Java, Indonesia

${ }^{3}$ Lecturer Management Department UIN Maulana Malik Ibrahim, Malang, East Java, Indonesia

Email:indrayati@ polinema.ac.id, erlin.melani@polinema.ac.id, slametphd@manajemen.uin-malang.ac.id Orcid ID: https://orcid.org/0000-0003-4943-7951 ${\text { https://orcid.org/0000-0001-6268-34312 }{ }^{2} \text { https://orcid.org/0000-0001-5583-5425 }}^{3}$

\section{Indonesia}

\section{A R T I C L E I N F O \\ Article history: Article \\ Received: $\quad 5$ April 2021 \\ Revised: $\quad 20$ April 2021 \\ Accepted: $\quad 27$ April 2021 \\ DOI: $10.47742 / i j b s s r . v 2 n 4 p 1$}

\section{A B S T R A C T}

The purpose of this study was to examine the effect of Corporate Governance on Intellectual Capital Disclosure. The sample used in this study consisted of 22 banking companies listed on the Indonesia Stock Exchange in 2015-2019. The data used is in the form of an annual report. The sampling technique in this study was to use purposive sampling. This study uses multiple regression analysis. The statistical analysis results show that partially the audit committee and external auditor variables have a significant positive effect on intellectual capital disclosure.

Meanwhile, the independent commissioner variable has no significant effect on intellectual capital disclosure. The ownership concentration variable harms intellectual capital disclosure. Simultaneously, the variables of the independent commissioner, ownership concentration, audit committee, and external auditor have a significant effect on intellectual capital disclosure.

Keywords: Independent Commissioner, Ownership Concentration, Audit Committee, External Auditor and Intellectual Capital Disclosure

\section{Introduction}

Corporate governance includes a series of relationships between company management, the board of commissioners, shareholders, and other stakeholders. The structures and mechanisms in corporate governance can be used to monitor fraudulent corporate management actions. Companies that apply the principles of good corporate governance in their business activities will be more transparent and responsible in providing information that complies with existing regulations or laws and information that is material and relevant to the interests of stakeholders. One of the vital pieces of information needed by stakeholders is information about intellectual capital.

The importance of intellectual capital in Indonesia has grown with PSAK No.19 (revised 2000) on intangible assets. The PSAK does not explain in detail about Intellectual Capital, but at least the Intellectual Capital has received attention with the issuance of this PSAK. According to PSAK No. 19, intangible assets are non-monetary assets that can be identified and do not have a physical form and are owned for use in producing or delivering goods or services, leased to other parties, or administrative purposes (IAI, 2002).

Examples of intangible assets according to PSAK No. 19 Paragraph 9 include science and technology, design and implementation of new systems or processes, licenses, intellectual property rights, knowledge of markets, and trademarks (including product brands/brand names). Besides, computer software, patents, copyrights, live film, customer lists, forest concession rights, import quotas, franchises, supplier or customer relationships, customer loyalty, marketing rights, and market share are also added (Ulum, 2009).

Following the latest company law, companies in the form of limited liability Companies (PT) and registered on the IDX are required to comply with Law No. 40 of 2007, and disclosure of intellectual capital is one of the types of information needed by users to determine the condition of the company in terms of mastery of science and technology (Wiliam, 2000; in Purnomisidhi, 2005).

The practice and disclosure of intellectual capital information is a logical consequence of implementing the concept of good corporate governance, which states that companies need to pay attention to stakeholder interests by establishing active cooperation following regulations. Thus, the company gets benefits, namely being able to maintain and maintain the company's long-term viability (Fitriani, 2012; Alizadeh, 2014; Hidalgo, 2011; Tulung, 2019; Dalwai, 2018).

\section{Literature Review}

\subsection{Agency Theory}

The agency theory developed by Johnson (as cited in Daniri, 2006) states that company management as agents for shareholders will act with full awareness of their interests, not as wise and wise and fair parties. Towards shareholders as assumed in the stewardship model. Contrary to stewardship theory, agency 
Vol: 2, Issue: 4

April/2021

https://ijbssrnet.com/index.php/ijbssr

DOI: http://dx.doi.org/10.47742/ijbssr.v2n4p1

http://iarpnet.org/

theory views that management cannot be trusted to act in the best possible way for the public interest in general and shareholders in particular. Based on this understanding, it can also be explained that agency theory is a theory that views company management as parties who have interests for shareholders. They will act for their interests consciously and not as parties who are wise and wise and fair to shareholders.

\subsection{Stakeholder Theory}

According to Daniri (2009), stakeholder theory emphasizes management's importance to coordinate with all parties involved in the company. Management is required to balance the interests of both shareholders and stakeholders as well as between stakeholders. This is to avoid conflicts of interest.

Stakeholder theory states that company management is expected to carry out activities desired by stakeholders and report them to stakeholders (Purnomoshidi, 2005). For this reason, the company is expected to carry out responsible programs related to the management of company resources, primarily Intellectual Capital.

The main objective of stakeholder theory is to help corporate managers understand their stakeholder environment and manage more effectively among their company's existing relationships. However, the broader aim of stakeholder theory is to assist corporate managers in increasing the value of their activities and minimizing losses to stakeholders. The core of the whole stakeholder theory lies in what will happen when the corporation and stakeholders lie in what will occur when the corporation and stakeholders carry out their relationship (Ulum, 2009).

\subsection{Legitimacy Theory}

Legitimacy is a psychological condition of taking sides of people and groups of people who are very sensitive to their surrounding environment symptoms, both physical and nonphysical (Hadi, 2011, p. 87). According to O'Donovan, 2002 (Hadi, 2011, p. 87) argues that organizational legitimacy can be seen as something that society gives to companies and something that companies want or seek from the community. Thus, legitimacy is a potential benefit or resource for the company to survive (going concern).

Gray et al., (1996) argue that legitimacy is a ". . .. a system-oriented view of organization and society. . . permits us to focus on the role of information and disclosure in the relationship between organizations, the state, individuals, and group ".

This definition implies that legitimacy is a company management system oriented towards taking sides with the community (society), individual government, and community groups. Therefore, as a system that prioritizes society's side, the company's operations must be congruent with the community's expectations.

Legitimacy theory is closely related to reporting on intellectual capital and is also closely related to using the content analysis method as a measure of the reporting. Companies are more likely to report their Intellectual Capital if they have a particular need to do so. This may occur when the company finds that the company is unable to legitimize its status based on tangible assets, which are generally recognized as a symbol of company success (Ulum, 2009).

\subsection{Independent Commissioner}

According to the Limited Liability Company Law No. 40 of 2007, states that independent commissioners have been adopted, namely in article 120 paragraph (1) and paragraph (2), notes:

1. The association's articles may stipulate 1 (one) or more independent commissioners and 1 (one)

2. principal commissioner.

3. As referred to in paragraph (1), the independent commissioner is appointed based on the GMS's resolution from a party that is not affiliated with the main shareholder, a member of the Board of Directors, and other members of the Board of Commissioners.

In the explanation of Article 120 paragraph (2) of the Company Law, it explains that:

"Independent Commissioners in the code of good corporate governance are Commissioners from outside parties. Thus, an independent commissioner is a member of the board of commissioners who are not affiliated with the board of directors, other members of the board of commissioners, and controlling shareholder, and is free from business or other relationships that may affect his ability to act independently or act solely for the benefit of the Company (Surya, 2006).

\subsection{Ownership Concentration}

In a company, the ownership structure will influence the motivation to supervise and monitor the management fiber company and its board of directors. Ownership concentration can occur due to differences in the proportion of share ownership listed on the IDX. So that from this difference, there are also differences in voting rights between majority shareholders and minority shareholders. The resulting difference from the proportion of share ownership also results in an initial conflict of interest within or outside the company. Ownership can be concentrated if most of the shares are owned by some individuals or groups so that these shareholders have a relatively large number of shares than other shareholders. Meanwhile, ownership is diversified if many shareholders own the company with the same number of shares (Yustiana, 2014).

\subsection{Audit Committee}

The audit committee is a committee under the board of commissioners, consisting of at least one independent commissioner and independent professionals from outside the company, whose responsibilities include helping auditors remain separate from management. In addition to the requirements of Bapepam-LK, audit committees are also needed in SOEs and banks. Most audit committees consist of three and sometimes five to seven members who are not part of company management (Elder et al., 2011).

\subsection{External Auditor}

A business dictionary external audit is defined as an audit conducted by an external (independent) body that meets the requirements. The purpose of which is to determine, among other 
Vol: 2, Issue: 4

April/2021

https://ijbssrnet.com/index.php/ijbssr

DOI: http://dx.doi.org/10.47742/ijbssr.v2n4p1

things, whether the accounting records are accurate and complete, whether they are prepared following the provisions of PSAK, and whether the reports prepared from the data present the financial position and results of financial operations fairly.

\subsection{Intellectual Capital}

Interest in intellectual capital started when Tom Stewart, in June 1991, wrote an article ("Brain Power-How Intellectual Capital is Becoming America's Intellectual Capital's Most Valuable Assets"), which put intellectual capital on the management plan. Stewart defines intellectual capital in his article as follows: "The sum of everything everybody in your company knows that gives you a competitive edge in the marketplace. It is intellectual material knowledge, information, intellectual property, an experience that can be put to use to create wealth. Intellectual capital is generally identified as the difference between a company's market value (the company's business) and the book value of the company's assets or its financial capital. This is based on an observation that since the late 1980s, most businesses' market value and specifically knowledge-based businesses have become greater than the value reported in financial statements based on calculations made by accountants Roslender and Fincham 2004 (in Ulum, 2009). So intellectual capital is knowledge, information, experience, capabilities, and competencies that can provide added value to the company in improving company performance so that profits can increase.

\subsection{Components of Intellectual Capital}

From several definitions of intellectual capital, other researchers develop more specific components of intellectual capital. According to Edvinsson and Malone 1997 (Ulum, 2009, p. 25) classifies that the value of intellectual capital in a company is the sum of the Company's Human Capital and Structural Capital. Meanwhile, IFAC (1998) classified intellectual capital into three categories: organizational capital, relational capital, and human capital. Other researchers such as Bontis et al. (2000) stated that in general, all researchers who classify intellectual capital identify it into three main categories, namely: human capital, structural capital, and customer capital.

Human capital is a combination of genetic inheritance, education, experience, and attitude about life and business. SC includes all non-human storehouses of knowledge in the organization. This includes databases, organizational charts, process manuals, strategies, routines, and anything else that makes the company value more than its material value. Whereas customer capital is the knowledge inherent in marketing channels and customer relationships, companies can develop it in business activities (Bontis et al., 2000, as cited in Ulum, 2009, p. 30).

\subsection{Measurement of Intellectual Capital}

If the company wants to increase company value, the company must think about what factors provide firm value information. Traditional business success indicators do not provide sufficient information about business success that can create value for the company. Another factor that companies must consider is intangible assets because, after all, these factors can affect the company's overall performance. Therefore, it is necessary to measure the intangible assets implied by the intellectual capital. Various methods have been offered to measure Intellectual Capital. One of them is the method developed by Pulic (1997). Produced by Public in 1997, which is designed to present information about the value creation efficiency of tangible assets and intangible assets owned by the company is an instrument to measure the performance of a company's intellectual capital. This approach is relatively easy and possible because it is constructed from the accounts in the company's financial statements (balance sheet, profit, and loss) (Ulum 2009b).

In summary, the formulations and stages of the calculation are as follows:

The first stage, Calculating the Value Added (VA), is calculated using a formula

$\mathrm{VA}=\mathrm{OUT}-\mathrm{IN}$

Where: OUT (Output) = total sales and other income

IN (Input) = selling expenses and additional costs (other than employee expenses)

The second stage, Calculating the Value Added Capital Employed (VACA, the ratio of VA to $\mathrm{CE}$ ), this indicator is used for VA created by one unit of Physical Capital. This ratio shows the contribution made by each company of $\mathrm{CE}$ to the organization's Value Added.

$\mathrm{VACA}=\mathrm{VA} / \mathrm{CE}$

Where: $\mathrm{VA}=$ Value Added

$\mathrm{CE}=$ Capital Employed: available funds (equity, net income)

The third stage, calculating the value-added human capital (VAHU, the ratio of VA to Intellectual Capital), this indicator shows how much VA can be generated with the funds spent on labor. This ratio shows the contribution made by each rupiah invested in $\mathrm{HC}$ to the organization's Value Added.

$\mathrm{VAHU}=\mathrm{VA} / \mathrm{HC}$

Where: $\mathrm{HC}=$ Human Capital: employee expenses

In the fourth stage, calculating structural capital valueadded (STVA), this indicator's ratio measures the amount of SC needed to produce 1 rupiah from VA and indicates how successful SC is in value creation.

STVA $=$ SC $/$ VA

Where: $\mathrm{SC}=$ Structural Capital: VA-HC

$\mathrm{VA}=$ Value Added

The fifth stage, calculating the value-added intellectual coeffective capitalist (VAICTM). VICTIM indicates that an organization's intellectual ability can also be considered a BPI (Business Performance Indicator).

\section{[VAIC]^ TM = VACA + VAHU + STVA}

This method has the advantage that the required data is relatively easy to obtain from various companies' sources and types (Pulic, 1997, in Ulum, 2009).

\subsection{Interaction Between Variables}

The Influence of Independent Commissioners on Intellectual Capital Disclosure

According to Haniffa and Cook (2002), the more the number of independent commissioners on the board, the higher 
Vol: 2, Issue: 4

April/2021

https://ijbssrnet.com/index.php/ijbssr

DOI: http://dx.doi.org/10.47742/ijbssr.v2n4p1

http://iarpnet.org/

the impact of the information disclosed. And with the characteristics of an independent Independent Commissioner who is independent (not tied to any relationship with the company) will decide on the independent commissioner who does not favor any of the company's interests. Although disclosure of intangible assets is still only voluntary, it is hoped that the disclosure of information regarding intangible assets (which includes intellectual capital) can be disclosed more specifically.

\section{The Effect of Ownership Concentration on Intellectual} Capital Disclosure

Companies with limited ownership are expected to have less information asymmetry between management and majority shareholders who generally have access to the information they need and can provide an active governance system that is difficult for smaller, more passive, and less-informed investors (Cormier et al. in Li et al., 2008). According to their wants and needs, large ownership can create a more significant moral hazard by exploring company-owned resources, including human resources.

\section{The Effect of the Audit Committee on Intellectual Capital Disclosure}

Li et al. (2008) stated that the larger the size of the audit committee in a company is expected to have a more significant influence in regulating the disclosure of intellectual capital practices (as quoted in Wahyuni and Rasmini, 2016). The audit committee also has the responsibility to supervise the reporting and disclosure of information in the financial statements. The audit committee can oversee and disclose information about intangible assets (including intellectual capital) because overall, the Intellectual Capital component can improve company performance and indirectly attract investors.

\section{The Effect of External Auditor Quality on Intellectual} Capital Disclosure

According to Kompasiana, 2015, the external auditor is a third-party alias not part of the organization. They perform assignments based on contracts governed by statutory provisions and professional standards that apply to external auditors. External auditors focus on the accuracy and understanding of historical events reflected in the organization's financial statements.

The external auditor is one of the determinants of the quality of disclosure reports made by the company. This external auditor's existence for guarantees that the reports prepared by the company are presented fairly. External auditors included in the Big-Four can be used to reference that the external auditors are qualified and have a better reputation to produce accurate, independent auditor reports. According to Barako (2007), although management's overall responsibility is to prepare company reports, external auditors can significantly influence the amount of information disclosed.

\subsection{Research Framework}

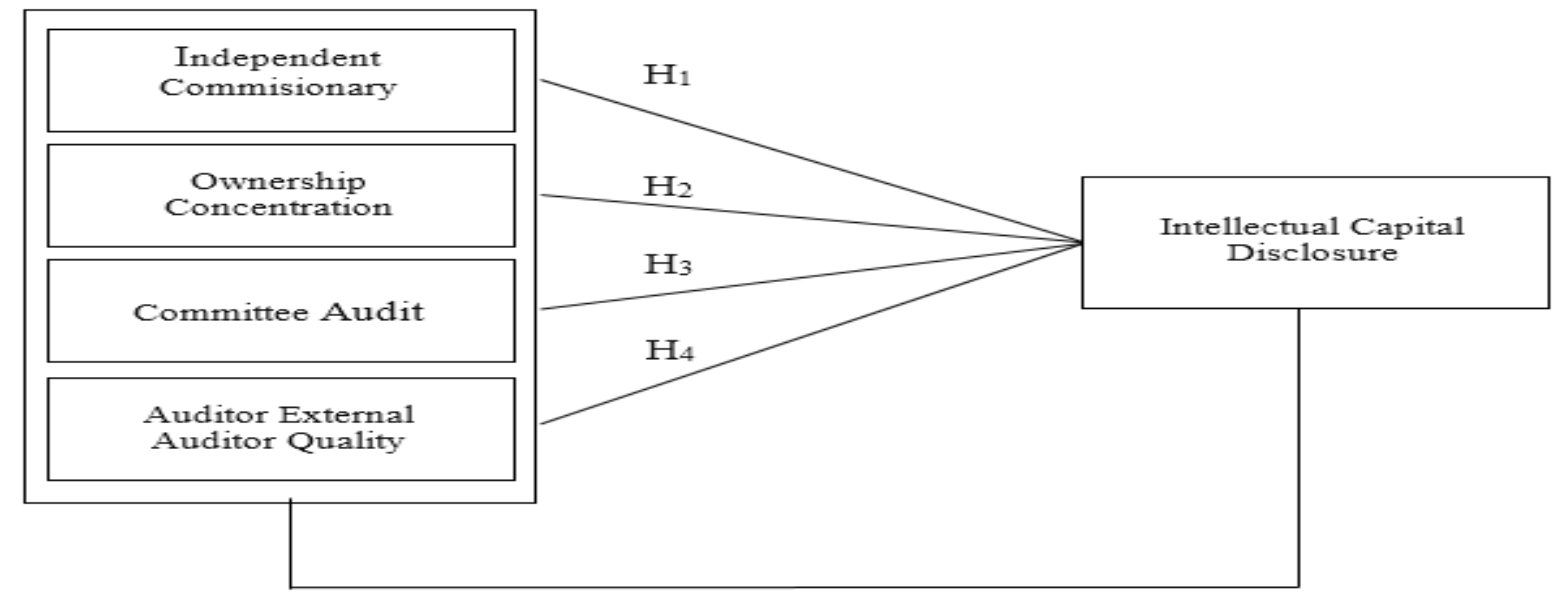

Figure 1. Research Framework

\subsection{Hypothesis}

H1: The Independent Commissioner has a positive effect on Intellectual Capital disclosure

H2: Ownership concentration has a positive effect on Intellectual Capital disclosure

H3: The Audit Committee has a positive effect on intellectual capital disclosure

H4: External Auditor Quality has a positive effect on Intellectual Capital disclosure

H5: Independent commissioners, ownership concentration, audit committee, and external auditors affect Intellectual Capital

\section{Results and Discussion}

\section{Descriptive Statistical Analysis}

Descriptive statistical analysis is used to present information related to the characteristics of the required variables in the form of maximum values, minimum values, mean, and standard deviation. The mean is used to measure the central importance of data distribution. Simultaneously, the standard deviation is the difference in the value of the data under study and its average value. Following are the results of the descriptive statistical test. 
Table 1. Test Results Statistik Descriptif

\begin{tabular}{|c|c|r|r|r|r|}
\hline Decription & $\mathbf{N}$ & \multicolumn{1}{c|}{ Minimum } & Maximum & \multicolumn{1}{c|}{ Mean } & Std.Deviation \\
\hline KI & 110 & 0,500 & 0,800 & 0,57127 & 0,079034 \\
\hline KK & 110 & 0,154 & 1,000 & 0,54841 & 0,205341 \\
\hline JR & 110 & 3,0 & 38,0 & 13,055 & 8,1543 \\
\hline AE & 110 & 0,0 & 1,0 & 0,782 & 0,4149 \\
\hline IC & 110 & 0,453 & 0,766 & 0,62415 & 0,64955 \\
\hline
\end{tabular}

Based on the calculation of the descriptive analysis found in table 9, it can be explained as follows:

1. The variable KI (Independent Commissioner, XI) has a minimum value of 0.5 , a maximum value of 0.8 , and a mean of 0.57127 with a standard deviation of 0.079034 .

2. In the variable $\mathrm{KK}$ (Ownership Concentration, X2) has a minimum value of 0.154 , a maximum value of 1.00 , and a mean of 0.54841 with a standard deviation of 0.205341 .

3. In the JR variable (Audit Committee has, X3), which is a proxy for the audit committee, it has a minimum value of 3.0, a maximum value of 38.0 , and a mean of 13.055 with a standard deviation of 8.1543 .
Vol: 2, Issue: 4

April/2021

https://ijbssrnet.com/index.php/ijbssr

DOI: http://dx.doi.org/10.47742/ijbssr.v2n4p1
4. The variable AE (External Auditor, X4) has a minimum value of 0.0 , a maximum value of 1.0 , and a mean of 0.782 with a standard deviation of 0.4149 .

5. The IC (Intellectual Capital, Y) variable has a minimum value of 0.453 , a maximum value of 0.766 and a mean of 0.62415 with a standard deviation of 0.064955 .

The standard deviation value shows how far the data variation is, if the normal deviation value is greater than the mean value, it means that the result is not excellent or heterogeneous. Based on the descriptive analysis results above, the mean value for each variable is greater than the standard deviation. So it can be concluded that the variables $\mathrm{X} 1, \mathrm{X} 2, \mathrm{X} 3, \mathrm{X} 4$, and $\mathrm{Y}$ do not occur homogeneously, which means that the data differences between companies are relatively small.

Table 2. Test Multikolinieritywith VIF Test

\begin{tabular}{|l|r|r|}
\hline \multirow{2}{*}{ Variable } & \multicolumn{2}{|c|}{ Collinearity Statistics } \\
\cline { 2 - 3 } & Tolerance & \multicolumn{1}{c|}{ VIF } \\
\hline KI & 0,922 & 1,085 \\
\hline KK & 0,796 & 1,256 \\
\hline JR & 0,843 & 1,186 \\
\hline AE & 0,783 & 1,277 \\
\hline
\end{tabular}

\section{Classic Assumption Test}

This classic assumption test consists of the normality test, heteroscedasticity test, multi-correlation test, linearity test, and autocorrelation test.

\section{Normality test}

The normality test aims to test whether confounding or residual variables have a normal distribution in the regression model. The normality test was carried out using the One-Sample Kolmogorov Smirnov test at the residual unstandardized value using an alpha of $5 \%$. If the value of asymptotic significance> 0.05 , the data is normally distributed. The normality test shows that the value is the asymptotic significance $(0.071)>0.05$, so it can be concluded that the data are normally distributed.

\section{Multicollinearity Test}

Data is said to be free from multicollinearity symptoms if the value of VIF is smaller than 10. The following are the results of the Multicollinearity test with the VIF value. The test results are presented in Table 2 , the independent tolerance variable value $(0.922 ; 0.796 ; 0.843 ; 0.783)$ is greater than 0.1 . Meanwhile, the VIF value of the independent variable (1.085; $1.256 ; 1.186 ; 1.277)$ is less than 10 . From these results, it is concluded that there is no multicollinearity in this regression model to be used in research.

\section{Heteroscedasticity test}

Based on this, it can be seen that the dots spread randomly both above and below the 0 on the $\mathrm{Y}$-axis and the spread does not form a certain pattern. This shows that this model is free from heteroscedasticity. So that this model fulfills the heteroscedasticity assumption.

\section{Autocorrelation Test}

The autocorrelation test aims to test whether in the linear regression model there is a correlation between confounding error in period $t$ and confounding error in period $t-1$ (previous). The autocorrelation test used is the Run Test. It can be seen in Appendix 3 that the Asymp. Sig (1-tailed) of $0.125>0.05$ so there is no autocorrelation symptom.

\section{Hypothesis Test}

\section{a. Simultaneous Test}

The hypothesis proposed is as follows:

H0= Independent commissioner, ownership concentration, audit committee, and external auditors do not affect intellectual capital. H5= Independent commissioner, ownership concentration, audit committee, and external auditors affect Intellectual Capital

The F statistical test shows whether all the independent or free variables included in the model have a joint influence on the dependent variable. Based on the Simultaneous test, it is known that the F-count value of 3.790 is greater than the F-table of 2.46 and a significance value of $0.006<0.05$. This means that 
Vol: 2, Issue: 4

April/2021

https://ijbssrnet.com/index.php/ijbssr

DOI: http://dx.doi.org/10.47742/ijbssr.v2n4p1

http://iarpnet.org/

$\mathrm{H} 0$ is rejected and $\mathrm{H} 5$ is accepted, so it can be concluded that the variables of the independent commissioner, ownership concentration, audit committee, and external auditor jointly or simultaneously influence the variable intellectual capital disclosure.

\section{b. Partial Test}

The $t$ statistical test shows how far the influence of one independent explanatory variable individually in explaining the variation of the dependent variable. The following are the regression results from the t-test with the previously created equation.

Table 3. Table Test Parsial (t)

\begin{tabular}{|l|l|r|r|r|r|}
\hline No & \multicolumn{1}{|c|}{ Variable } & \multicolumn{1}{c|}{ B } & \multicolumn{1}{c|}{ Beta } & \multicolumn{1}{c|}{ t } & \multicolumn{1}{c|}{ Sig } \\
\hline 1 & (Contant) &, 575 & & 10,903 &, 000 \\
\hline 2 & KI &, 056 &, 068 &, 716 &, 475 \\
\hline 3 & KK &,- 064 &,- 201 & $-1,964$ &, 052 \\
\hline 4 & JR &, 002 &, 261 & 2,624 &, 010 \\
\hline 5 & AE &, 032 &, 205 & 1,988 &, 049 \\
\hline
\end{tabular}

Based on the results of regression testing, the following regression formula can be drawn up: $\mathrm{Y}=0.575+0.056 \mathrm{x} \_1-0.064 \mathrm{x} \_2+0.002 \mathrm{x} \_3+0.032 \mathrm{x} \_4$

This equation can be interpreted as follows:

A constant of 0,575 states that if the independent variable is considered constant, then the average Intellectual Capital disclosure is high, namely $57 \%$.

The regression coefficient on the Independent Commissioner variable is 0.056 . A positive coefficient value indicates that the Independent Commissioner has a positive effect on Intellectual Capital Disclosure.

The regression coefficient on the ownership concentration variable is -0.064 . The negative coefficient value indicates that ownership concentration harms intellectual capital disclosure.

The regression coefficient on the Audit Committee variable is 0.002 . A positive coefficient value indicates that the Audit Committee has a positive effect on Intellectual Capital Disclosure.

The regression coefficient on the External Auditor variable is 0.032 . A positive coefficient value indicates that the External Auditor has a positive effect on Intellectual Capital Disclosure.

Then from the regression equation, the hypothesis testing can be done as follows:

1. Effect of Independent Commissioners on Intellectual Capital Disclosure.

The hypothesis proposed is as follows:

$\mathrm{H} 0=$ Independent Commissioner has no positive effect on disclosure of Intellectual Capital.

H1=Independent Commissioner has a positive effect on Intellectual Capital disclosure.

Based on table 11, it is known that the significance level is $0.475>0.05$, and the count value is smaller than the table $(0.716$ <1.65936) so that this means that $\mathrm{H} 0$ is accepted and $\mathrm{H} 1$ is rejected. So, the Independent Commissioner does not have a significant effect on Intellectual Capital. And the beta value of 0.068 indicates that the Independent Commissioner variable on Intellectual Capital disclosure is $6.8 \%$. And this influence is positive so that if the number of Independent Commissioners in a company increases, it will increase Intellectual Capital disclosures.

\section{The Effect of Ownership Concentration on Intellectual} Capital Disclosure.

The hypothesis proposed is as follows:

$\mathrm{H} 0=$ Ownership concentration does not have a positive effect on disclosure of intellectual capital.

$\mathrm{H} 2=$ Ownership concentration has a positive effect on Intellectual Capital disclosure.

Based on table 11, it is known that the significance level is $0.052>0.05$ and the count value is smaller than the $t$ table $(-1.964$ $<1.65936)$, so that this means that $\mathrm{H} 0$ is accepted and $\mathrm{H} 2$ is rejected. So, the Independent Commissioner does not have a significant effect on Intellectual Capital. And the beta value of 0.201 indicates that the Independent Commissioner variable's influence on the disclosure of Intellectual Capital is $-20.1 \%$. And this effect is negative, which means that the greater the concentration of ownership of an individual or group of an entity, the lower the disclosure of intellectual capital is.

3.The Effect of the Audit Committee on Intellectual Capital Disclosure.

The hypothesis proposed is as follows:

$\mathrm{HO}=$ Audit Committee has no positive effect on intellectual capital disclosure.

H4 = The Audit Committee has a positive effect on intellectual capital disclosure.

Based on table 11, it is known that the level of significance is $0.010>0,05$ and the value of $t$ is more significant than $t$ table (1.988> 1.65936) so that this means that $\mathrm{H} 0$ is rejected and $\mathrm{H} 4$ is accepted. So, the Audit Committee has a significant effect on Intellectual Capital. And the beta value of 0.261 indicates that the Audit Committee variable's influence on Intellectual Capital disclosure is $26.1 \%$. And this influence is positive so that if the size of the Audit Committee (proxied by the number of meetings) increases, it will increase the number of Intellectual Capital disclosures.

\section{Disclosure}

4.The Effect of External Auditors on Intellectual Capital

The hypothesis proposed is as follows: 
Vol: 2, Issue: 4

April/2021

https://ijbssrnet.com/index.php/ijbssr

DOI: http://dx.doi.org/10.47742/ijbssr.v2n4p1

http://iarpnet.org/

H0 = External Auditor has no positive effect on Intellectual Capital disclosure.

H3 = External Auditor has a positive effect on Intellectual Capital disclosure

Based on table 11, it is known that the level of significance is $0.049>0.05$ and the value of $t$ is greater than $t$ table (2.624> 1.65936) so that this means that $\mathrm{H} 0$ is rejected and $\mathrm{H} 3$ is accepted. So, the Audit Committee has a significant effect on Intellectual Capital. And the beta value of 0.205 indicates that the External Auditor variable's influence on the disclosure of Intellectual Capital is $20.5 \%$. And this influence is positive so that if an entity uses a qualified External Auditor, it will affect the quality of the company's information disclosure, including Intellectual Capital's disclosure.

\section{Determination Coefficient Test}

The coefficient of determination (R2), in essence, measures how far the model's ability to explain the variation in the dependent variable. The coefficient of determination is between zero and one. The small value of $\mathrm{R} 2$ means that the independent variables' ability to explain the variation in the dependent variable is minimal. A value close to 1 (one) means that the independent variables provide almost all the information needed to predict the dependent variable's variation.

Based on the results of regression testing, it was found that the coefficient of determination (R2) was $12.6 \%$ (can be seen in appendix 4). These results can be concluded that the independent variable influences intellectual capital disclosure by $12.6 \%$. Simultaneously, the remaining $87.4 \%$ is influenced by other variables outside the variables described in this study.

Discussion

The effect of the Independent Commissioner on Intellectual Capital disclosure

The Independent Commissioner variable does not affect disclosure of Intellectual Capital (ICD). The partial test results show that the t-count value is smaller than the t-table $(0.716$ $<1.65936)$, and the significance level is greater than the probability value of $0.475>0.05$. And the regression coefficient value is 0.056 , indicating that if the number of independent commissioners is one value, disclosure of the dependent variable (ICD) will increase by 0.056 . This test rejects $\mathrm{H} 1$, which states that the Independent Commissioner variable positively affects the disclosure of Intellectual Capital (ICD).

These results support the agency theory, which states that company management as an agent for shareholders will act according to their own will, not be fair to all shareholders. So it indicates that the more significant the proportion of Independent Commissioners is not necessarily able to understand and represent the interests of minority shares and all company stakeholders so that the functions of internal control and control at the top level do not work correctly. This study's results contradict research by Wahyuni and Rasmini (2016) and White et al. (2007), which stated that independent commissioners had a positive effect on disclosure of Intellectual Capital. However, the results of this analysis are supported by research conducted by Ho and Wong (2001), Khomsiyah (2003), Arifah (2012), and
Zulkarnaen and Mahmud (2013), which state that Independent Commissioners do not affect information disclosure. This supports the explanation that independent commissioners' ineffective function in companies as a monitoring tool is because the appointment of Independent Commissioners is only to fulfill corporate governance rules, not to enforce corporate governance. The existence of independent commissioners in the company is quite essential, but if it is not balanced with an increase in performance, it will not impact company performance.

\section{Effect of Ownership Concentration on Intellectual Capital disclosure}

The ownership concentration variable does not affect disclosure of Intellectual Capital (ICD). The partial test results show that the value of the t-count is smaller than the table ($1.964<1.65936)$, and the significance level is greater than the probability value of $0.052>0.05$. And the value of the regression coefficient is -0.064 , indicating that if the number of ownership concentrations increases by one value, the dependent variable disclosure (ICD) will decrease by -0.064 . This test rejects $\mathrm{H} 2$, which states that the ownership concentration variable has a positive effect on Intellectual Capital's exposure (ICD).

This result contradicts the stakeholder theory, which states that management must balance both shareholder's and stakeholders' interests. The possibility of information assimilation is very large because large shareowners will have unilateral information that the other party may not know. The emergence of moral hazard on ownership with a high concentration will also use the information they have to carry on a potential business without providing information to other parties. Another reason that shows that ownership concentration does not affect disclosure of intellectual capital is that high concentration can lead to policies or a unilateral decision due to voting rights in the General Meeting of Shareholders (GMS) so that the results achieved are not optimal, company policies are ineffective and the achievement of company goals is not good. So, the company's governance is not optimal so that automatically intellectual capital is not widely disclosed (Nugroho, 2012). This study's results are different from those of Bukh (2005) and Ulum (2015), which state that ownership concentration influences disclosure of intellectual capital. However, this study's results are supported by White et al. (2007) and Nugroho (2012), which states that ownership concentration does not affect disclosure of intellectual capital. Significant ownership can lead to more significant moral hazards by exploring resources. owned by the company, including human resources according to the wants and needs of the brand

\section{The Effect of the Audit Committee on Intellectual Capital Disclosure}

The Audit Committee variable affects the disclosure of Intellectual Capital (ICD). This is evidenced by the regression testing results, which can be seen from the coefficients table (attachment 4). The partial test results show that the t count value is greater than the t-table (1.988> 1.65936) and the significance level is greater than the probability value of $0.010>0,05$. dependent (ICD) will increase by 0.002 . This test accepts H3 
Vol: 2, Issue: 4

April/2021

https://ijbssrnet.com/index.php/ijbssr

DOI: http://dx.doi.org/10.47742/ijbssr.v2n4p1

which states that the Audit Committee variable has a positive effect on disclosure of Intellectual Capital (ICD).

The results of the analysis are supported by the theory of legitimacy, which states that the company's management system is oriented towards taking sides with the community, individual government, and community groups. This is related to the duties of the audit committee related to reporting the findings of external auditors. Suaryana (2005) states that the audit committee is in charge of assisting the board of commissioners in monitoring the financial reporting process by management to increase financial reports' credibility. The audit committee's duties include reviewing accounting policies implemented by the company, assessing internal control, reviewing external reporting systems, and compliance with regulations. To carry out its duties, the audit committee should carry out formal communication between the board, management, external auditors, and internal auditors. Formal communication between the audit committee, internal auditors, and external auditors will ensure that the internal and external audit processes are carried out correctly.

Arifah (2012) states that the audit committee influences the disclosure of relevant information values. IC disclosure is one of them. Likewise, Taliyang's (2011) 's analysis states that only the number of audit committee meetings positively affects the three corporate governance variables. In contrast, the other variables do not influence information disclosure (Intellectual Capital). The same results are also shown by Wahyuni and Rasmini (2016). However, different results are given by Fitriani (2012), Zulkarnaen and Mahmud (2013), and Ho and Wong (2001), who states that the audit committee does not influence the extent of intellectual capital disclosure contained in an annual report.

\section{Disclosure}

The Effect of External Auditors on Intellectual Capital

The External Auditor variable affects the disclosure of Intellectual Capital (ICD). The partial test results show that the value of $t$ is greater than the t-table $(2.624>1.65936)$ and the significance level is greater than the probability value of $0.049>$ 0.05 . And the value of the regression coefficient is 0.032 , indicating that if the quality of external auditors increases by one value, the dependent variable disclosure (ICD) will increase by 0.032. This test accepts H4, which states that the Audit Committee variable has a positive effect on disclosure of Intellectual Capital (ICD).

The analysis results are supported by the theory of legitimacy, which states that the company's management system is oriented towards taking sides with the community, individual government, and community groups. This proves that the External Auditor is one of the determinants of the disclosure of reports made by the company, including disclosure of Intellectual Capital. This external auditor's existence is to ensure that the reports prepared by the company are presented fairly. According to Barako (2007), although management's overall responsibility is to prepare company reports, external auditors can significantly influence the amount of information disclosed. Research conducted by Whiting and Woodcock (2009) supports that external auditors affect intellectual capital disclosure. Meanwhile, research conducted by Prameswari (2014) states that there is no influence between external auditors and disclosure of intellectual capital.

\section{CONCLUSION}

This study examines how corporate governance's influence on intellectual capital disclosure in banking companies listed on the IDX in 2011-2015. The test was carried out by multiple regression analysis with four independent variables (Independent Commissioner, Ownership Concentration, Audit Committee, and External Auditor) and one dependent variable (Intellectual Capital disclosure). The results of the regression analysis show that Corporate Governance (as proxied by Independent Commissioners, Ownership Concentration, Audit Committee, and External Auditors) has a simultaneous effect on the disclosure of Intellectual Capital because the significance value is $0.006<0.05$ and the Fount value of 3.790 is more significant than F-table. They are amounting to 2.46.

Then for the partial test (T-test), the results obtained are that two variables are significant to Y. The first is that the audit committee has a positive effect on intellectual capital disclosure, this result is supported by legitimacy theory and because the level of significance is $0.010>0,05$ and the value $t$ count is greater than t table $(1.988<1.65936)$, so that $\mathrm{H} 3$ is accepted. The second is that the External Auditor has a positive effect on the disclosure of Intellectual Capital, the theory of legitimacy supports this result and because the level of significance is $0.049>0.05$ and the value of $\mathrm{t}$ is more significant than $\mathrm{t}$ table $(2.624<1.65936)$, so that $\mathrm{H} 4$ is accepted. While the Independent Commissioner variable does not affect disclosure of intellectual capital, this result is supported by agency theory and because the level of significance is $0.475>0.05$ and the count is smaller than the $t$ table $(0.716<1.65936)$ so that $\mathrm{H} 1$ is rejected. And the ownership concentration variable does not affect disclosure of intellectual capital. This result is contrary to stakeholder theory and because the level of significance is $0.052>0.05$ and the t-count is smaller than the t-table $(-1.964<1.65936)$, so that $\mathrm{H} 2$ is rejected. So, the Corporate Governance that is implemented in the company has not been fully implemented properly. The reality often makes it challenging to implement Corporate Governance consistently.

\section{REFERENCES}

Arifah, Dista Amalia. (2012). The Effect of Corporate Governance Mechanism on Intellectual Capital Disclosure: Intensive IC Companies. Journal of Indonesian Accounting and Finance Volume 9 Number 2, December 2012

Barako, Tibe. (2007). Stockholders' effect to CSRI. in The New EU (Journal). UMI 3473607. Nova Southeastern University. 
Vol: 2, Issue: 4

April/2021

https://ijbssrnet.com/index.php/ijbssr

DOI: http://dx.doi.org/10.47742/ijbssr.v2n4p1

Bontis, N. (2000), Assessing Knowledge Assets: A Review of the Models Used to Measure Intellectual Capital, HTTP: //www.business.queensu.ca/kbe.

Bontis, Nick. (2002). The Strategic Management of Intellectual Capital and Organizational Knowledge. USA.Oxford

Daniri, Achmad Mas (2006). Good Corporate Governance: Concepts and Applications in the Indonesian Context. Second Edition. Jakarta. Ray Indonesia

Elder Randal J., Mark S. Blaslly, Alvin A. Arens, Amir Abadi Jusuf. (2011). Audit Assurance Services. Jakarta. Four Salemba

Fitriani, Ayu Erika. (2012). The Effect of Corporate Governance Structure on Intellectual Capital Disclosure. Semarang. Faculty of Economics, Diponegoro University

Ghazali Imam. (2009). Multivariate Analysis Application with SPSS Program. Semarang. Publishing Agency of Diponegoro University Semarang

Hadi Noor. (2011). Corporate Social Responsibility. First Edition. Yogyakarta. Graha Ilmu

Haniffa, R.M., and T.E. Cooke. (2002), Culture, Corporate Governance and Disclosure in Malaysian Corporations, ABACUS, Vol. 38, No. 3, pp. 317-349.

Ho, Simon, S.M., and Kar Shun Wong. (2000).A Study of The Relationship Between Corporate Governance Structures and the Extent of Voluntary Disclosure. Journal of International Accounting, Auditing \& Taxation 10 (2001) 139-156

Indra Surya, Ivan Yustiavandana. (2006). Implementation of Good Corporate Governance: Setting aside special rights for business continuity. Jakarta. Kencana Prenada Media Group

J. Guthrie, R. Petty, K. Yongvanich, F. Ricceri, (2004). Using content analysis as a research method to inquire into intellectual capital reporting, Journal of Intellectual Capital, Vol. 5 Issue: 2, pp.282-293, DOI: 10.1108 / 14691930410533704

Jensen, M.C. and Meckling, W.H. (1976). Theory of the firm: managerial behavior, agency costs and ownership structure, Journal of Finance Economics, Vol. 3, October, p. 305-60.

Joy Elly Tulung, Ivonne Sarang, Stevanus Pandia, 2019, The Influence of Corporate governance on the Intellectual capital Disclosure: A Study on Indonesian Private Banks, Banks And Bank Systems, Vol 13 Issue 4, 2018, https://ssrn.com/ abstract $=3308020$.

Kartikasari, Aristya. (2015). The Influence of Corporate Governance Attributes on intellectual Capital Disclosure. Semarang.Diponegoro University

Keenan, J. and Aggestam, M. (2001). Corporate Governance and Intellectual Capital: some conceptualizations. Corporate Governance: An International Review. 9: 259-275. DOI: 10.1111 / 1467-8683.00254

Khomsiyah. (2003). The Relationship between Corporate Governance and Information Disclosure: Simultaneous Testing. Trisakti University

Law of the Republic of Indonesia Number 40 of . (2007) concerning Limited Liability Companies. Jakarta.www.hukumonline.com

Li et al. (2008). Intellectual Capital Disclosure and Corporate Governance Structure in UK Firms. Accounting and Business Research $38(2)$.

Mavridis, D.G. (2004). The intellectual capital performance of the Japanese banking sector, Journal of Intellectual Capital, Vol. 5. No. 1, p 92-115.

Mulyadi. (2007). Planning and Management Control Systems. Jakarta. Four SalembaPer Nikolaj Bukh, Christian Nielsen, Peter Gormsen, Jan Mouritsen, (2005). Disclosure of information on intellectual capital in Danish IPO prospectuses, Accounting, Auditing \& Accountability Journal, Vol. 18 Issue: 6, pp.713-732, DOI: 10.1108 / 09513570510627685

Purnomosidhi, B. (2006). Public Disclosure Practices of Intellectual Capital on the JSE. Indonesian Journal of Accounting Research, Vol. 9. No. 1 page 1- 20.

Rahmat Alizadeh, Seyed Ali Nabavi Chashmi, Asghar Jahani Bahnamiri, 2014, Corporate governance and intellectual capital, DOI: 10-5267 / j.msl.2013.11.014.

Rahmawati. (2012). Financial Accountancy Theory. Yogyakarta. Graha Ilmu

Ruth Hidalgo, Emma Garcia-Meca, Isabel Martinez Conesa, 2011, Corporate governance and Intellectual capital disclosure, DOI: 10-1007 / s 10551-010-0692-x. Journal of Business Ethics (2011) 100: 483-495.

Stewart, T.A. (1997). Intellectual Capital: The New Wealth of Organization, HTTP: //www.intellectualcapital.com

Sugiyono. (2016). Quantitative Research Methods, Qualitative, and $R$ \& D. Bandung.Alfabeta

Sutedi, Adrian. (2012). Good Corporate Governance. First Edition. Jakarta. Sinar Grafika

Sveiby, K. E. (1997). The New Organizational Wealth: Managing \& Measuring Knowledge-based Assets. Berret-Koehler Publishers. Sydney. 
Vol: 2, Issue: 4

April/2021

https://ijbssrnet.com/index.php/ijbssr

DOI: http://dx.doi.org/10.47742/ijbssr.v2n4p1

Taliyang, Siti Mariana. (2011). Intellectual Capital Disclosure And Corporate Governance Structure: Evidence In Malaysia. International Journal of Business and Management Vol. 6, No. 12; December 2011

Tamanna Dalwai, Syeeda Shafiya Mohammadi, (2018), Intellectual capital and corporate governance: an evaluation of Oman's financial sector companies, Journal Of Intellectual capital, https://doi.org/10-1108/JIS-09-2018-0151.

Ulum, Ihyaul, Imam Ghozali, Agus Purwanto. (2014) Construction of Performance Measurement Models and Intellectual Capital Disclosure Frameworks. Journal of Multiparadigma Accounting. Vol 5. No.3.Malang, December 2014

Ulum, Ihyaul. (2009). Intellectual Capital. First Edition. Yogyakarta. Graha Ilmu

University Press.

Wahyuni, Made Arie, Ni Ketut Rasmini. (2016). The Effect of Corporate Governance Mechanisms. Journal of Economic Studies Bulletin. Vol. 21. No. 1. February 2016

White, G, Alina L, and Greg T. (2007). Drivers of Voluntary Intellectual Capital Disclosure in Listed Biotechnology Companies. Journal of Intellectual Capital, 8 (3), 517-537.

Whiting H And James Woodcock. (2009) Intellectual Capital Disclosures by Australian Companies Accounting and Finance Association of Australia and New Zealand (AFAANZ)

Yustiana, Pretty Brilliant. (2012). The Effect of Corporate Governance Structure on Intellectual Capital Disclosure. Semarang. Diponegoro University 